\title{
Are overweight and obesity associated with increased risk of cesarean delivery in Mexico? A cross-sectional study from the National Survey of Health and Nutrition
}

Alexander Brenes-Monge ${ }^{1}$, Biani Saavedra-Avendaño ${ }^{2}$, Jacqueline Alcalde-Rabanal ${ }^{2}$ and Blair G. Darney ${ }^{3,4^{*}}$ (D)

\begin{abstract}
Background: In Mexico, obesity is a major public health problem; 71\% of adults are overweight or obese. The proportion of deliveries by cesarean is also very high (45\%). Women of reproductive age with overweight or obesity may be at higher risk of cesarean.

Methods: We conducted a cross-sectional study to test the association between overweight and obesity (using body mass index, BMI) and cesarean delivery in Mexico using data from the 2012 National Survey of Health and Nutrition (ENSANUT). Our sample included women of reproductive age at the time of survey who reported a live birth between 2006 and 2012. We used bivariate statistics and a multivariate logistic regression model to test the association between measured BMI and self-reported cesarean delivery. We included individual, clinical, and household level confounders and used survey weights to produce population estimates.

Results: Our sample consisted of 4,570 women (population $N=7,447,541$ ). Overall, 44\% of the women reported a cesarean at last delivery. We found differences in the proportion of cesarean delivery by BMl group (normal = 39\%; $95 \% \mathrm{Cl}$ [35-43]; overweight =42\%; 95\% Cl [38-45]; obesity =52\%; 95\% Cl [48-57]; $p<0.001)$. In multivariable models controlling for socio-demographic and clinical characteristics, we found a strong and independent association between obesity and cesarean delivery among multiparous women, compared with multiparous women with normal BMI (obesity aOR: 1.60; $95 \%$ Cl [1.21-2.12]).

Conclusions: We provide new evidence about the proportion of women with overweight and obesity who deliver in Mexico. Multiparous women with obesity are at higher risk of cesarean delivery in Mexico than multiparous women with normal body mass index. Given the high prevalence of both obesity and cesarean delivery in Mexico, this relationship is salient for women, health care providers, and the health system.

Efforts to reduce the cesarean deliveries rate need to take the obesity epidemic into account.
\end{abstract}

Keywords: Body mass index, Overweight, Obesity, Pregnancy, Mode of delivery, Cesarean delivery

\footnotetext{
* Correspondence: darneyb@ohsu.edu

${ }^{3}$ Center for Population Health Research, National Institute of Public Health

(INSP), Cuernavaca, Morelos, Mexico

${ }^{4}$ Department of Obstetrics and Gynecology, Oregon Health and Science

University, Portland, OR, USA

Full list of author information is available at the end of the article
}

(c) The Author(s). 2019 Open Access This article is distributed under the terms of the Creative Commons Attribution 4.0 International License (http://creativecommons.org/licenses/by/4.0/), which permits unrestricted use, distribution, and reproduction in any medium, provided you give appropriate credit to the original author(s) and the source, provide a link to the Creative Commons license, and indicate if changes were made. The Creative Commons Public Domain Dedication waiver (http://creativecommons.org/publicdomain/zero/1.0/) applies to the data made available in this article, unless otherwise stated. 


\section{Introduction}

In the last 25 years, the prevalence of obesity has doubled worldwide [1]; in Mexico, 71\% of adults are overweight or obese, with higher proportions in women than in men [2]. Overweight and obesity prevalence has also risen among pregnant women in Mexico, more than doubling in the past 30 years [3], which could increase the risk of obstetric and perinatal complications, compared to women with a normal Body Mass Index (BMI) [4-11].

Several studies have documented positive associations between overweight and/or obesity and complications during pregnancy and delivery, such as hypertensive disorders [12-14] and gestational diabetes [15-17]; in US populations those occur most frequently in pregnant women of Hispanic descent [18]. Increased time of labor [19-24], dystocia, and increased risk of cesarean delivery (CD) have also been found to be associated with overweight/obesity [25-27]. It is thus important to examine mode of delivery in the context of complications associated with obesity.

In Mexico, the overwhelming majority (94\%) of women deliver in health facilities, and the proportion of deliveries via cesarean reached 45\% of all births in 2012 [28]. This proportion of CD is considered high relative to the World Health Organization's (WHO) target cesarean rate of $10-15 \%$ of all births [29]. In addition to clinical indications for $\mathrm{CD}$, preferences of both women and physicians influence the use of $C D$, which suggests that some cesareans are performed in Mexico without following established clinical criteria [28].

The relationship of BMI and cesarean delivery had been studied previously; a meta-analysis reported a positive association between cesarean delivery and overweight, obese, and severely obese women [30]. However, studies of mode of delivery in Mexico have focused on receipt of antenatal care and socio-demographic differences [31]; we have no data about the relationship of overweight and obesity and CD.

Given the high prevalence of both overweight/obesity and $\mathrm{CD}$ in Mexico, this is a salient issue for women, health care providers, and the health system. The aim of this study was to determine the relationship between overweight/obesity (measured using BMI) and cesarean delivery in Mexican women. We hypothesized that overweight/obesity would be independently associated with $\mathrm{CD}$ in the Mexican population.

\section{Methods}

\section{Data and sample}

We conducted a cross-sectional study using data from the 2012 National Survey of Health and Nutrition (Encuesta Nacional de Salud y Nutricion, ENSANUT); the 2016 ENSANUT does not include information about delivery so these are the most recent data available. The survey uses probabilistic sampling and is representative at the state level and urban and rural strata. It is conducted approximately every 5 years through face to face interviews and includes anthropometric measurements of a subsample [2]. The ENSANUT survey collects written informed consent from all participants and only deidentified data are publically available. (Detailed information regarding ENSANUT is available at http://ensanut. insp.mx/). The ENSANUT includes a reproductive health service utilization module asked only of women 12-49 years old at time of survey who reported a live birth in the 5 years preceding the survey (between 2006 and 2012; Fig. 1). Our analytic sample included women with reproductive health data and with complete data of anthropometric measurements of weight and height, (85\% had complete information; Fig. 1).

Our dependent variable was self-reported mode of delivery of the last pregnancy (vaginal delivery or $C D$ ); $C D$ included both planned and emergency cesareans. Our key independent variable was BMI, calculated from data of the anthropometric measurements of weight and height, using the formula (weight (kilograms) / height (in meters $\left.{ }^{2}\right)$; adolescent mothers $(<20$ years) were categorized by standard deviations of age-specific BMI [27]. Data were categorized as either normal (BMI 18.5 $\leq 24.9$ ), overweight (BMI 25-29.9), or obese (BMI $\geq 30$ ) [28]. We collapsed BMI into commonly used categories $[32,33]$, which permits comparison with previous literature. Women with low weight $(\mathrm{BMI}<20)$ were excluded, because we considered this group as a separate risk condition of prenatal and perinatal complications by itself (Fig. 1). [29-31], and not the focus of this study. The reference group for all analyses were women with a normal BMI.

We included several covariates related to prenatal care, comorbidities, and complications. Prenatal covariates were: parity (nulliparous and multiparous), antenatal care initiation (early -in the first trimester- or late -after the first trimester-) and the total number of prenatal consultations, categorized according to Mexican government guidelines (at least five consultations or fewer than five consultations) [32]. We included pre-existing diabetes mellitus and hypertension as well as an indicator for self-reported presence of any complications during pregnancy, including hypertension disorders, gestational diabetes, infections (urinary or sexually transmitted diseases), anemia and threatened miscarriage. We also included the self-reported presence of any complications during labor and delivery (malpresentation, obstructed labor, preterm birth, and postpartum hemorrhage). We included type of health facility where the delivery occurred (employment based insurance facilities, public insurance facilities and private facilities). 


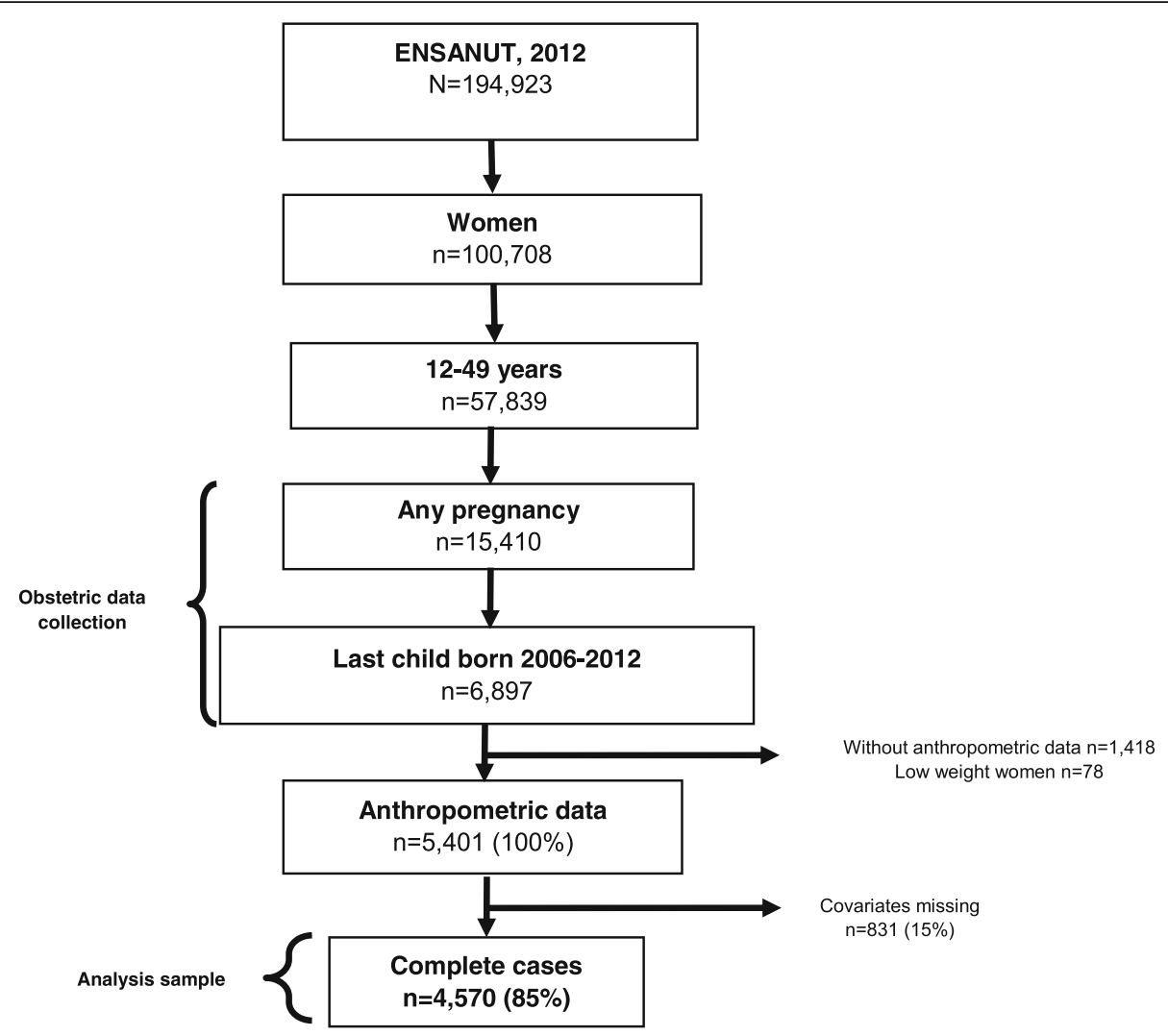

Fig. 1 Flow diagram of analysis sample selection

We also included several socio-demographic variables that could be associated with our exposure and/or outcome. We included woman's age at delivery, categorized in five-year groups. We measured education by the highest level achieved, (secondary/middle school or lower, high school, and greater than high school). We included household socioeconomic status in quintiles (quintile I being the poorest). The 2012 ENSANUT household socioeconomic indicator is based on household materials and ownership of consumer goods and generated using imputation methods [33].

We included indigenous ethnicity, measured by whether anyone in the household speaks an indigenous language, $[34,35]$ and geographic region (northern, central, centralwestern, south-southeast, taken directly from the state classification used by the ENSANUT) [26]. We included health insurance, categorized as either employment-based insurance (for those who work in the formal sector), public insurance (run by the Ministry of Health for lowincome people) or no coverage (women who reported no health insurance affiliation). In addition, we calculated the time elapsed between date of delivery and anthropometric measurement (date of survey), in order to be able to control for recall bias in variables as well as changes that may have occurred in BMI between delivery and the survey.

\section{Analysis}

We first used chi-square tests to assess bivariate differences in sociodemographic and health characteristics by BMI category. We also disaggregated self-reported complications during pregnancy and delivery and used chisquare to test for differences in individual complications by BMI. We also used chi-square tests to assess differences in our main outcome (mode of delivery) by BMI. We used survey weights in all analyses to account for the complex sampling scheme of the ENSANUT and produce population estimates.

We compared demographic, health characteristics between our analytic sample and those women excluded due to missing data, and there were no differences in our outcome and in most covariates, an additional file shows this in more detail [see Additional file 1]. Women excluded due to missing data were more likely to reside in indigenous households and in the central-western and southsoutheast region, and more likely to deliver in public and private facilities (versus employment-based facilities).

We first ran a bivariate model including only BMI and $\mathrm{CD}$, stratified by parity (nulliparous vs multiparous). We then developed a multivariate logistic regression model stratified by parity, to test the association between mode of delivery and BMI. 
Covariates included in the final logistic model were age at delivery, education level, socioeconomic status, indigenous ethnicity, initiation of prenatal care, antenatal consultations, diabetes mellitus, hypertension, complications during pregnancy grouped, complications at delivery grouped, place of delivery, and health insurance.

We also performed a sensitivity analysis stratifying by the time elapsed between date of delivery and anthropometric measurement (less than 2 years, two-four years, more than 4 years) according to parity. The interpretation of our findings was similar, suggesting that recall bias was not a problem; an additional file shows this in more detail [see Additional files 2 \& 3]. We therefore simply included elapsed time between delivery and BMI measurement as a control variable in our final regression model. We ran several models to compare including complications as a dichotomous variable (presence of any complication yes or no), then we disaggregated the complications and only included those individual complications that were significantly different by BMI in bivariate tests. Finally, we tested a model in which we only included those complications during pregnancy and delivery that are clinically related with overweight and obesity (hypertension, preeclampsia-eclampsia and diabetes mellitus). Using complications as a binary variable produced the same results and a better-fitting model so we used presence or absence of complications during pregnancy or delivery in our analysis, in addition to diabetes and hypertension.

\section{Results}

Our analytic sample included 4,570 women between 12 and 49 years old who reported a live birth between 2006 and 2012. This sample represents a population of 7,277, 541 Mexican women. Overweight and obesity prevalence of women of reproductive age was $66.2 \%$ (36.4\% overweight and $29.8 \%$ obese) Table 1 . Overweight and obese women were more likely to be older than normal BMI women. The distribution of socioeconomic status was similar by BMI (Table 1).

Women with overweight and obesity were more likely to be multiparous compared with normal BMI (normal BMI 64\%; 95\% confidence interval (CI) [60-68]; overweight 76\%; 95\% CI [73-79]; obesity 80\%; 95\% CI [7684]; $p=0.001$; Table 1). Women with overweight and obesity were also more likely to report existing diabetes (overweight 2\% [95\% CI 1-4] and obesity 3\% [95\% CI 24] vs. normal BMI $1 \%$ [95\% CI 0-1]; $p=0.013$ ) and hypertension (normal BMI 6\%; 95\% CI [5-9]; overweight 7\%; 95\% CI [5-9] and obesity 13\%; 95\% CI [10-16]; $p=0.001$ ).

No differences in the presence of any complications (collapsed any/none) during pregnancy or delivery between BMI groups were found (normal BMI 61\%; 95\% CI [57-64]; overweight 58\%; 95\% CI [54-62], obesity
61\%; 95\% CI [57-65]; $p=0.442$ ). When we disaggregated complications during pregnancy we found differences by BMI in hypertension (normal BMI 13\%; 95\% CI [10-15]; overweight $16 \%$; $95 \%$ CI [13-18] $p<0.05$; obesity $20 \%$; 95\% CI [17-24]; $p=0.004)$, preeclampsia-eclampsia (normal BMI 5\%; 95\% CI [4-8]; overweight 9\%; 95\% CI [7-12]; obesity $11 \%$; 95\% CI [9-14]; $p=0.001)$ and gestational diabetes mellitus (normal BMI 1\%; 95\% CI [1, 2]; overweight 3\%; 95\% CI [2-4]; obesity 5\%; 95\% CI [4-8]; $\mathrm{p}=0.001$ ). Figure 2. Complications at delivery - collapsed and disaggregated - did no show differences by BMI.

Women with overweight and obesity reported a proportion of CD higher than women with normal BMI (normal 39\%; 95\% CI [35-43]; overweight 42\%; 95\% CI [38-45]; obesity 52\%; 95\% CI [48-57]; $p=0.001$ ); (Fig. 3).

Results from the bivariate model including only BMI and $\mathrm{CD}$ segregated by parity (nulliparous vs multiparous) show a relationship between multiparous women with obesity and $C D$ (unadjusted odds ratio $=1.91 ; 95 \%$ CI [1.44-2.55]; see Additional file 4).

Our multivariable logistic regression model stratified by parity (nulliparous vs multiparous) show that multiparous women with obesity had higher odds of CD compared to women with normal BMI after controlling for confonders (adjusted odds ratio $(\mathrm{aOR})=1.89 ; 95 \% \mathrm{CI}$ [1.36-2.63]; Table 2.). The presence of complications during delivery was also associated with $\mathrm{CD}$, in both nulliparous (aOR $=3.50$; 95\% CI [2.06-5.94]) and multiparous women $(\mathrm{aOR}=4.01 ; 95 \%$ CI $[3.01-5.35])$. In addition, both nulliparous and multiparous women who delivered at private facilities had higher odds of $C D$ compared with those who delivered at social security facilities (nulliparous aOR $=1.95$; 95\% CI [1.08-3.53]; multiparous aOR $=2.51 ; 95 \%$ CI $[1.72-3.68]$.

\section{Discussion}

We found that in Mexico, maternal overweight and obesity are common, as is cesarean delivery, and furthermore, that obesity is independently associated with cesarean delivery in multiparous women, controlling for sociodemographic and clinical characteristics that are associated with BMI and CD. Just over $42 \%$ of women with overweight and $52 \%$ of women with obesity had a $\mathrm{CD}$, compared with $39 \%$ of women with normal BMI, and 1.89 higher odds of $\mathrm{CD}$ were found in multiparous women with obesity when compared with normal BMI women, controlling for socio-demographic and health factors. Our results support our hypothesis that in Mexico, high BMI (obesity) is independently associated with $\mathrm{CD}$, controlling for socio-demographic and health characteristics.

Overall, the proportion of deliveries via CD in our study was $44 \%$, which supports previous evidence in Mexico 
Table 1 Characteristics of the study population by body mass index

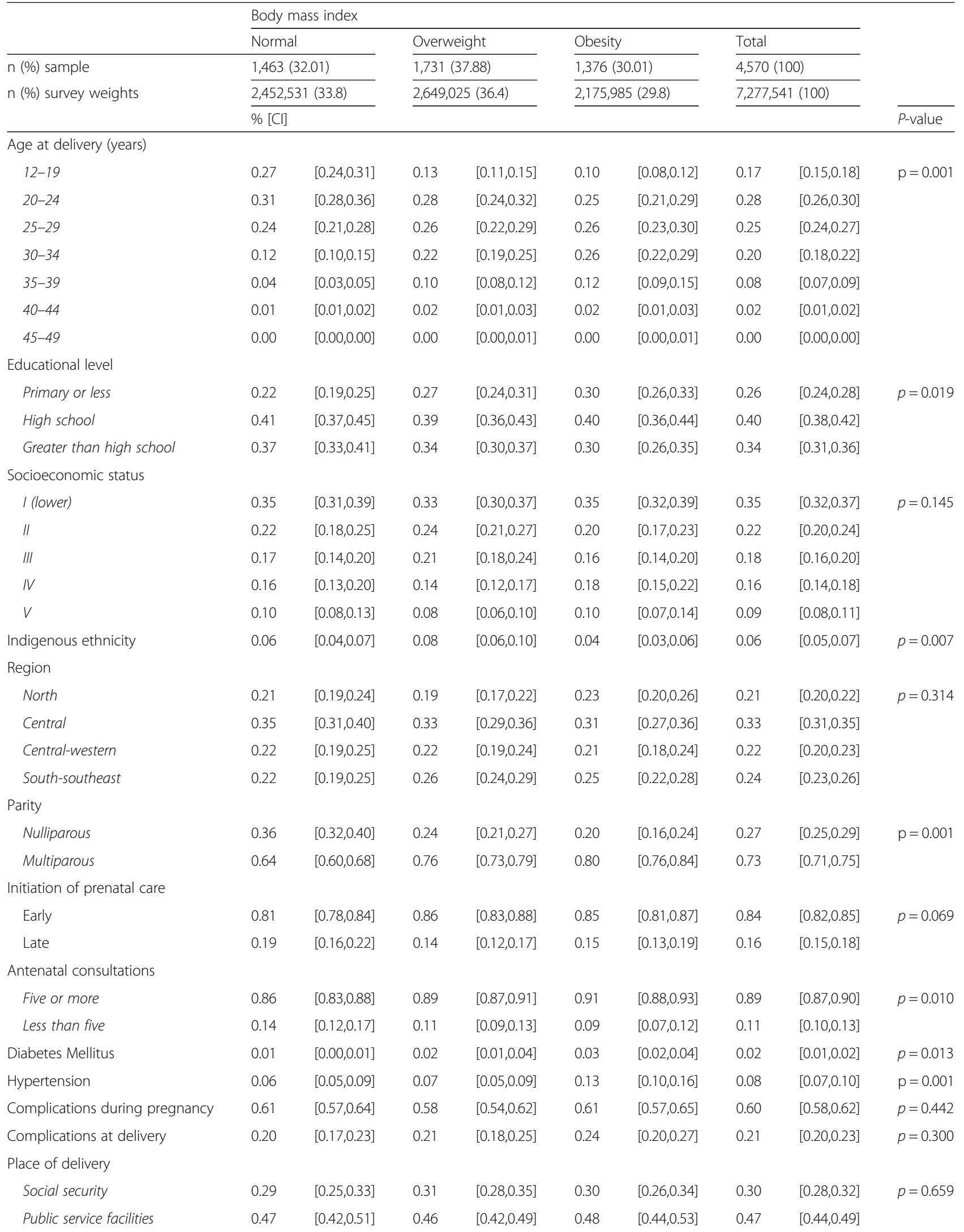


Table 1 Characteristics of the study population by body mass index (Continued)

\begin{tabular}{|c|c|c|c|c|c|c|c|c|c|}
\hline & \multicolumn{8}{|c|}{ Body mass index } & \\
\hline & \multicolumn{2}{|c|}{ Normal } & \multicolumn{2}{|c|}{ Overweight } & \multicolumn{2}{|c|}{ Obesity } & \multicolumn{2}{|c|}{ Total } & \\
\hline n (\%) sample & \multicolumn{2}{|c|}{$1,463(32.01)$} & \multicolumn{2}{|c|}{$1,731(37.88)$} & \multicolumn{2}{|c|}{$1,376(30.01)$} & \multicolumn{2}{|c|}{$4,570(100)$} & \\
\hline \multirow[t]{2}{*}{ n (\%) survey weights } & \multicolumn{2}{|c|}{$2,452,531(33.8)$} & \multicolumn{2}{|c|}{$2,649,025(36.4)$} & \multicolumn{2}{|c|}{$2,175,985(29.8)$} & \multicolumn{2}{|c|}{$7,277,541(100)$} & \multirow[b]{2}{*}{$P$-value } \\
\hline & \multicolumn{4}{|c|}{$\%[\mathrm{Cl}]$} & & & & & \\
\hline Private facilities & 0.25 & {$[0.21,0.29]$} & 0.23 & {$[0.20,0.26]$} & 0.22 & {$[0.18,0.26]$} & 0.23 & {$[0.21,0.26]$} & \\
\hline \multicolumn{10}{|l|}{ Health insurance } \\
\hline Social security & 0.27 & {$[0.23,0.31]$} & 0.31 & {$[0.28,0.34]$} & 0.29 & {$[0.26,0.33]$} & 0.29 & {$[0.27,0.31]$} & \multirow[t]{3}{*}{$p=0.478$} \\
\hline Public service & 0.50 & {$[0.46,0.55]$} & 0.50 & {$[0.46,0.54]$} & 0.50 & {$[0.46,0.54]$} & 0.50 & {$[0.48,0.53]$} & \\
\hline No coverage & 0.23 & {$[0.19,0.27]$} & 0.19 & {$[0.16,0.23]$} & 0.21 & {$[0.17,0.25]$} & 0.21 & {$[0.19,0.23]$} & \\
\hline
\end{tabular}

All proportions include survey weights

[28], and is comparable with CD rates in Brazil (45.9\%), the Dominican Republic (41.9\%) and Cuba (35.6\%) [34], positioning Latin America and the Caribbean region with the highest $C D$ rates worldwide [35, 36]. A recent study reported better maternal and neonatal outcomes when CD rates do not exceed 19\% of all births [37]; the proportion of $\mathrm{CD}$ found in our study is three times higher than the WHO recommendation of CD [29].

Studies in Latin American countries have reported that high $C D$ rates were positively associated with severe maternal morbidity and mortality and higher fetal mortality rates [38]. Furthermore, increases in CD rates is not associated with improvements in other perinatal outcomes [39]. Results from a meta-analysis including cohort studies of pregnant women with anthropometric measurements shows higher odds of cesarean in women with obesity, consistent with our results [40]. A Canadian study that compared maternal outcomes between women with normal BMI and extreme obesity also found a positive association between extreme obesity and $\mathrm{CD}[41]$.
Studies in nulliparous women have reported a positive relationship between a high BMI (overweight and obesity) and CD [42-44], which we did not find in our study. However, a study focused on the risk of caesarean section in obese women analysed by parity reported highest $\mathrm{CD}$ rates in multiparous women associated with a high rate of repeat elective $\mathrm{CD}$ [45]. This finding could be related to a policy of scheduling pre-labour $\mathrm{CD}$ for all women with one previous scar without attempting a trial of labour [46].

We found women with any self-reported complications at delivery had higher adjusted odds of $\mathrm{CD}$ compared with women who did not report any complications.

The same positive association between high BMI and cesarean was found in multiparous women without complications, as reported in previous studies [47].

Pre-pregnancy BMI has been studied previously in Mexico, focused on pregnancy, fetal and neonatal complications as the primary outcome [48-50]. This previous literature has not focused on mode of delivery as an

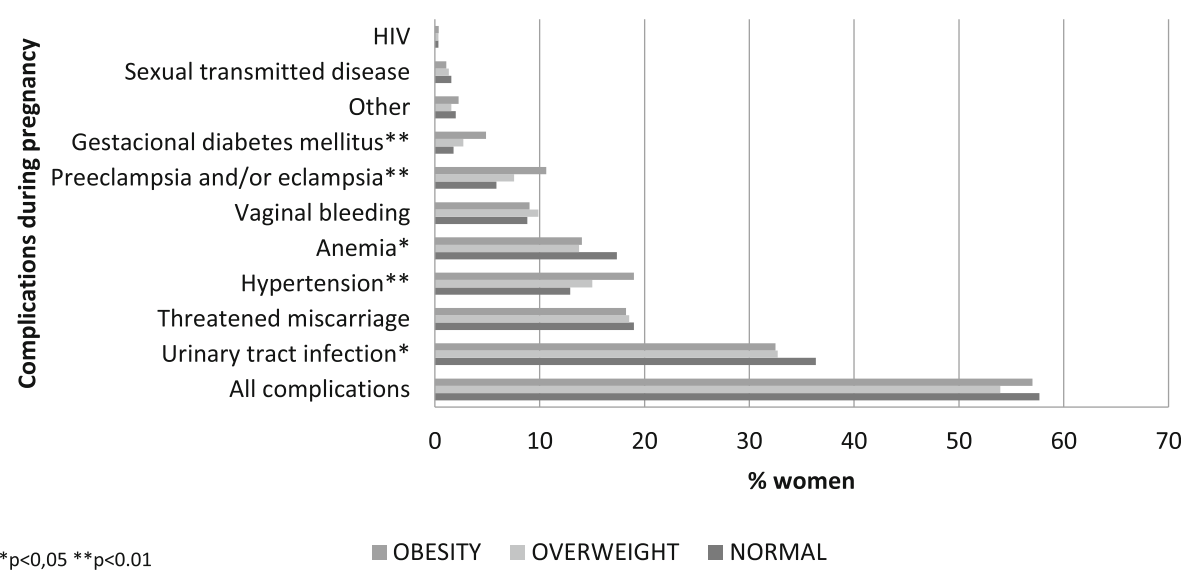

Fig. 2 Complications during pregnancy by body mass index, Mexico, 2012 


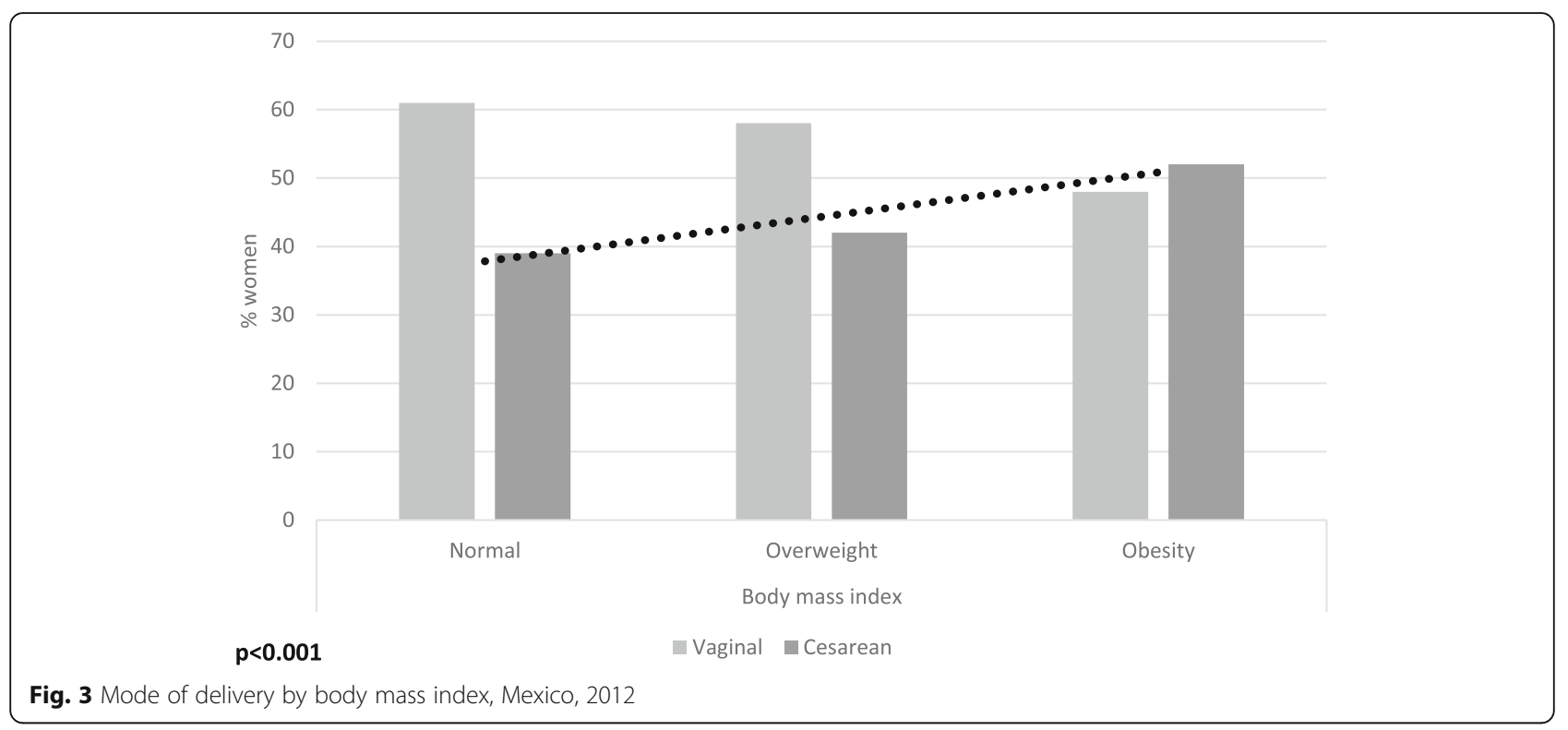

outcome. Our study fills a gap in the literature, especially given the concurrent epidemics of obesity and $C D$ in Mexico. Although overweight and obesity are not defined as a $\mathrm{CD}$ indication in clinical practice guidelines [51], our results shows a strong and independent association between high BMI and CD in multiparous women. Our findings suggest that the high $C D$ rate and obesity epidemic are linked. Health care providers should consider BMI as important factor in maternal interventions to reduce negative maternal and perinatal outcomes [47, 52].

The Mexican Health System has recognized the importance of reducing cesareans and has created official standards, technical guidelines and clinical practice guidelines to regulate and reduce the CD rate [51]. Despite these efforts, implementation of these recommendations has faced challenges and high rates persist as reported here and previously [53-55]. Contributing factors may be the lack of training of health professionals, resistance to change and maintenance of practices not based on evidence, a perception of $\mathrm{CD}$ as harmless, quick and effective by pregnant women and physicians $[56,57]$. Increased demand of CD by women from poor families, following trends documented in rich people, have also been reported [52].

The most important limitation of study is the timing of BMI measurement; we do not have prepregnancy BMI measurements, rather we have BMI measurments following delivery, at the time of survey. However, we use a large nationally representative sample with anthropometric BMI measurement (not self-report, which was previously reported to have an important bias, particularly in women $[58,59])$. We explored potential bias introduced by time elapsed between delivery and survey through stratified analyses (Additional files $2 \& 3$ ) and results were robust. We provide the first population-level assessment of BMI and $C D$ in Mexico. Our outcome and covariates (except our exposure, BMI) are self-report, which could potentially affect our results so we performed multiple sensitivity analyses with variables sensitive to recall bias (such as complications during delivery) to ensure our results were robust to model specification. Our study included only those women with complete anthropometric data, and women excluded were more vulnerable than those with complete data. The missing variables in the women excluded from the study sample corresponded to those of self-report related to sociodemographic characteristics and health history (Additional file 1). There was no lack of data in the BMI exposure variable and the type of delivery outcome. When analyzing the differences between women included and excluded from the study sample, no differences were found in the BMI exposure variable and the type of delivery outcome. Women with missing data could be those with greater vulnerability, which could limit the generalization of study results. Future studies should consider exploring in depth if these differences could be affecting the health outcome in the most vulnerable women.

\section{Conclusion}

The results of our study provide evidence in the Mexican population of the relationship between high BMI and risk of $\mathrm{CD}$. Our results further offer new evidence about the proportion of women with overweight and 
Table 2 Association between body mass index (BMI) and cesarean deliveries according to parity, Mexico, 2012

\begin{tabular}{|c|c|c|c|c|c|c|}
\hline \multirow[b]{2}{*}{ Sample n (\%) } & \multicolumn{3}{|c|}{ Primiparous } & \multicolumn{3}{|c|}{ Multiparous } \\
\hline & \multicolumn{3}{|c|}{$1,093(23.9)$} & \multicolumn{3}{|c|}{$3,477(76.1)$} \\
\hline \multirow[t]{2}{*}{ Population estimates N (\%) } & \multicolumn{3}{|c|}{$1,943,104(26.7)$} & \multicolumn{3}{|c|}{$5,334,438(73.3)$} \\
\hline & $\mathrm{aOR}$ & \multicolumn{2}{|c|}{$[95 \% \mathrm{Cl}]$} & $\mathrm{aOR}$ & \multicolumn{2}{|c|}{$[95 \% \mathrm{Cl}]$} \\
\hline \multicolumn{7}{|l|}{ Body mass index (ref.: normal) } \\
\hline Overweight & 0.63 & 0.39 & 1.00 & 1.31 & 0.98 & 1.74 \\
\hline Obesity & 1.30 & 0.76 & 2.23 & 1.89 & 1.36 & 2.63 \\
\hline Late antenatal care initiation & 1.10 & 0.63 & 1.92 & 1.08 & 0.78 & 1.49 \\
\hline Five or more antenatal consultations & 0.52 & 0.29 & 0.95 & 0.74 & 0.49 & 1.10 \\
\hline Complications during pregnancy & 0.92 & 0.60 & 1.40 & 1.17 & 0.92 & 1.50 \\
\hline Complications at delivery & 3.50 & 2.06 & 5.94 & 4.01 & 3.01 & 5.35 \\
\hline Diabetes Mellitus & 0.50 & 0.12 & 2.10 & 1.47 & 0.61 & 3.54 \\
\hline Hypertension & 1.56 & 0.69 & 3.50 & 1.02 & 0.67 & 1.57 \\
\hline \multicolumn{7}{|l|}{ Place of delivery (ref:: social security) } \\
\hline Public service facilities & 0.89 & 0.54 & 1.46 & 1.09 & 0.76 & 1.57 \\
\hline Private facilities & 1.95 & 1.08 & 3.53 & 2.51 & 1.72 & 3.68 \\
\hline \multicolumn{7}{|l|}{ Age at delivery (ref.: 12-14 years) } \\
\hline $15-19$ & 0.83 & 0.26 & 2.60 & 6.07 & 1.11 & 33.10 \\
\hline $20-24$ & 1.19 & 0.38 & 3.73 & 8.64 & 1.64 & 45.55 \\
\hline $25-29$ & 2.40 & 0.67 & 8.58 & 9.81 & 1.87 & 51.49 \\
\hline $30-34$ & 1.66 & 0.37 & 7.55 & 13.05 & 2.49 & 68.25 \\
\hline $35-40$ & 11.94 & 1.95 & 73.12 & 12.90 & 2.47 & 67.41 \\
\hline $40-44$ & 3.36 & 0.30 & 38.16 & 14.14 & 2.54 & 78.60 \\
\hline+45 & - & - & - & - & - & - \\
\hline \multicolumn{7}{|l|}{ Educational level (ref.: primary or less) } \\
\hline High school & 0.72 & 0.41 & 1.27 & 1.22 & 0.94 & 1.59 \\
\hline Greater than high school & 0.73 & 0.39 & 1.37 & 1.61 & 1.16 & 2.23 \\
\hline \multicolumn{7}{|c|}{ Socioeconomic status (ref.: I quintile, lower) } \\
\hline "l & 0.89 & 0.50 & 1.58 & 1.30 & 0.96 & 1.77 \\
\hline III & 0.76 & 0.43 & 1.34 & 1.68 & 1.19 & 2.38 \\
\hline IV & 1.07 & 0.57 & 2.00 & 1.33 & 0.86 & 2.04 \\
\hline V & 1.14 & 0.53 & 2.42 & 1.89 & 1.10 & 3.27 \\
\hline Indigenous ethnicity & 0.84 & 0.41 & 1.71 & 0.68 & 0.42 & 1.10 \\
\hline \multicolumn{7}{|l|}{ Region (ref.: north) } \\
\hline Central & 1.21 & 0.71 & 2.05 & 1.42 & 0.99 & 2.03 \\
\hline Central-western & 1.36 & 0.75 & 2.45 & 1.21 & 0.90 & 1.63 \\
\hline South-southeast & 2.04 & 1.17 & 3.57 & 1.06 & 0.75 & 1.52 \\
\hline \multicolumn{7}{|l|}{ Health insurance (ref.: social security) } \\
\hline Public service & 0.73 & 0.44 & 1.22 & 0.71 & 0.51 & 1.01 \\
\hline No coverage & 0.92 & 0.50 & 1.67 & 0.95 & 0.62 & 1.45 \\
\hline \multicolumn{7}{|c|}{ Time elapsed between delivery and BMI measurement (ref.: $<2$ years) } \\
\hline $2-4$ & 0.99 & 0.63 & 1.57 & 0.95 & 0.68 & 1.31 \\
\hline$>4$ & 1.22 & 0.75 & 1.98 & 0.92 & 0.67 & 1.26 \\
\hline
\end{tabular}


obesity who deliver in Mexico, which can be used to inform maternal health programs. Given the high prevalence of both obesity and $C D$ in Mexico, this relationship is salient for women, health care providers, and the health system. Efforts to reduce the $\mathrm{CD}$ rate need to take the obesity epidemic into account.

\section{Additional files}

Additional file 1: Table S1. Characteristics of women excluded vs. included of analysis sample, Mexico, 2012. (DOCX 14 kb)

Additional file 2: Table S2. Association between body mass index and cesarean delivery in nulliparous women, by time elapsed between delivery and BMI measurement, Mexico, 2012. (DOCX 16 kb)

Additional file 3: Table S3. Association between body mass index and cesarean delivery in multiparous women, by time elapsed between delivery and BMI measurement, Mexico, 2012. (DOCX 16 kb)

Additional file 4: Table S4. Association between body mass index (BMI) and cesarean deliveries according to parity, Mexico, 2012. (Unadjusted odds ratio). (DOCX $12 \mathrm{~kb}$ )

\section{Abbreviations}

aOR: adjusted odds ratio; BIC: Bayesian Information Criterion; BMI: Body mass index; CD: Cesarean delivery; Cl: confidence interval; ENSANUT: Encuesta Nacional de Salud y Nutricion (National Survey of Health and Nutrition); WHO: World Health Organization

\section{Acknowledgments}

The authors would like to thank Drs. Jonathan M. Snowden and Aaron B. Caughey for hosting ABM for a research internship, which facilitated the completion of this analysis. A preliminary version of this analysis was presented at the XXII FIGO World Congress, Rio de Janerio, Brazil, 2018 [60].

\section{Authors' contributions}

ABM, BSA, JAR, and BGD conceptualized and designed the study methodology. ABM performed data curation and analysis and drafted the manuscript. BGD and BSA supervised analysis and visualization of data. ABM, $B S A, J A R$ and $B G D$ reviewed and edited the manuscript. All authors read and approved the final manuscript.

\section{Funding}

This work was supported by the Society of Family Planning National [SFPRF9-JI2; Darney, PI]. And by grant number K12HS022981 from the Agency for Healthcare Research and Quality. The content is solely the responsibility of the authors and does not necessarily represent the official views of the Agency for Healthcare Research and Quality. The funders had no role in the study design, analysis or interpretation of data, or writing of this article.

\section{Availability of data and materials}

The datasets generated during and/or analysed during the current study are available in the ENSANUT repository, [https://ensanut.insp.mx/index.php]. To access the Data Bases and Documentation section of the ENSANUT, a registration form must be complete. Subsequently, a username and password to access will be delivered. [2].

\section{Ethics approval and consent to participate}

This study was submitted for review and approved by the ethics committee of the National Institute of Public Health of Mexico (April 5, 2016, Cl 821). The ENSANUT survey collects written informed consent from all participants and only de-identified data are publically available.

\section{Consent for publication}

Not applicable.

\section{Competing interests}

The authors declare that they have no competing interests.

\section{Author details}

'Center for Evaluation Research and Surveys, National Institute of Public Health (INSP), Cuernavaca, Morelos, Mexico. ${ }^{2}$ Center for Health Systems Research, National Institute of Public Health (INSP), Cuernavaca, Morelos, Mexico. ${ }^{3}$ Center for Population Health Research, National Institute of Public Health (INSP), Cuernavaca, Morelos, Mexico. ${ }^{4}$ Department of Obstetrics and Gynecology, Oregon Health and Science University, Portland, OR, USA.

Received: 8 May 2018 Accepted: 30 June 2019

Published online: 11 July 2019

\section{References}

1. World Health Organization WHO. Obesity and overweight Fact sheet: WHO World Health Organization; 2017. Available from: http://www.who.int/ mediacentre/factsheets/fs311/en/. [cited 2018 Jan 29]

2. Gutiérrez JP, Rivera-Dommarco J, Shamah-Levy T, Villalpando-Hernández S, Franco A C-NL, Romero-Martínez M H-ÁM. Encuesta Nacional de Salud y Nutrición. Cuernavaca; 2012. Available from: https://ensanut.insp.mx/ informes/ENSANUT2012ResultadosNacionales.pdf. [cited 2017 Oct 23]

3. Zonana-Nacach A, Baldenebro-Preciado R, Ruiz-Dorado MA. Efecto de la ganancia de peso gestacional en la madre y el neonato. Salud Publica Mex. 2010;52(3):220-5.

4. Ranjkesh F, Pakniat H, Mohammadi F. The Impact of Body Mass Index on Pregnancy Outcome. J Midwifery Reprod Heal. 2015;3(2):361-7 Available from: http://jmrh.mums.ac.ir/article_4049.html. [cited 2018 Jan 30].

5. Valdés Yong M, Hernández Núñez J, Chong León L, González Medina IM، García Soto MM. Revista Cubana de Obstetricia y Ginecologia. Rev Cuba Obstet Ginecol. 2014;40:13-23 Available from: http://scielo.sld.cu/scielo. php?script=sci_arttext\&pid=S0138-600X2014000100003. [cited 2018 Jan 30].

6. Factores de riesgo para diabetes gestacional en población obstétrica en tres instituciones de Medellín, Colombia. Estudio de casos y controles | CampoCampo | Revista Colombiana de Obstetricia y Ginecología. Available from: https://revista.fecolsog.org/index.php/rcog/article/view/187. [cited 2018 Jan 30]

7. Smith GCS, Shah I, Pell JP, Crossley JA, Dobbie R. Maternal obesity in early pregnancy and risk of spontaneous and elective preterm deliveries: a retrospective cohort study. Am J Public Health [Internet]. 2007;97(1):157-162. Available from: http://www.ncbi.nlm.nih.gov/ pubmed/17138924. [cited 2018 Jan 30]

8. De la Calle FMM, Armijo LO, Martín BE, Sancha NM, Magdaleno DF, Omeñaca TF, et al. Sobrepeso y obesidad pregestacional como factor de riesgo de cesárea y complicaciones perinatales. Rev Chil Obstet Ginecol. 2009:74(4):233-8 Available from: https://scielo.conicyt.cl/scielo.php?script=sci_arttext\&pid=\$071 7-75262009000400005\&lng=en\&nrm=iso\&tlng=en. [cited 2018 Jan 31].

9. Leddy MA, Power ML, Schulkin J. The impact of maternal obesity on maternal and fetal health. Rev Obstet Gynecol. 2008;1(4):170-8 Available from: http://www.ncbi.n/m.nih.gov/pubmed/19173021. [cited 2018 Jan 31].

10. Martínez ME, Pond E, Wertheim BC, Nodora JN, Jacobs ET, Bondy M, et al. Association between parity and obesity in Mexican and Mexican-American women: findings from the Ella binational breast Cancer study. J Immigr Minor Health. 2013:15(2):234-43 Available from: http://www.ncbi.nlm.nih. gov/pubmed/22618357. [cited 2018 Jan 31]

11. Nava PD, Garduño AA, Pestaña SM, San-tamaría MF, Vázquez GDA, Camacho $\mathrm{RB}$, et al. Obesidad pregestacional y riesgo de intolerancia a la glucosa en el embarazo y diabetes gestacional. Rev Chil Obs Ginecol. 2011;76(1):10-4 Available from: https://scielo.conicyt.cl/pdf/rchog/v76n1/ art03.pdf. [cited 2018 Jan 31].

12. Diago Caballero D, Vila Vaillant F, Ramos Guilarte E, Garcia Valdés R. Revista Cubana de Obstetricia y Ginecologia. Revista Cubana de Obstetricia y Ginecología Centro Nacional de Informacion de Ciencias Medicas. 2011;37: 448-56 Available from: http://scielo.sld.cu/scielo.php?script=sci_arttext\&pid= S0138-600X2011000400002. [cited 2018 Jan 31].

13. Suárez González JA, Preciado Guerrero R, Gutiérrez Machado M, Cabrera Delgado MR, Marín Tápanes Y, Cairo González V. Revista Cubana de Obstetricia y Ginecologia. Vol. 39, Revista Cubana de Obstetricia y Ginecología. Centro Nacional de Informacion de Ciencias Medicas; 2013. 311 p. Available from: http://scielo.sld.cu/scielo.php?script=sci_arttext\&pid= S0138-600X2013000100002. [cited 2018 Jan 31]

14. Mostello D, Jen Chang J, Allen J, Luehr L, Shyken J, Leet T. Recurrent preeclampsia. Obstet Gynecol. 2010;116(3):667-72 Available from: http:// www.ncbi.nlm.nih.gov/pubmed/20733450. [cited 2018 Jan 31]. 
15. Mission JF, Marshall NE, Caughey AB. Pregnancy risks associated with obesity. Obstet Gynecol Clin N Am. 2015;42(2):335-53 Available from: http:// linkinghub.elsevier.com/retrieve/pii/S0889854515000224.

16. Ramos EV, Isandra L, Rojas B. Frecuencia y factores de riesgo asociados con la aparición de Diabetes Mellitus Gestacional Frequency and risk factors associated with appearance of gestational diabetes mellitus. 2011;37(4):50212 Available from: http://scielo.sld.cu/scielo.php?script=sci_arttext\&pid=\$013 8-600X2011000400007. [cited 2018 Jan 31].

17. Koyanagi A, Zhang J, Dagvadorj A, Hirayama F, Shibuya K, Souza JP, et al. Macrosomia in 23 developing countries: an analysis of a multicountry, facilitybased, cross-sectional survey. Lancet. 2013;381(9865):476-83 Available from: http://www.ncbi.nlm.nih.gov/pubmed/23290494. [cited 2018 Jan 28].

18. Tanaka M, Jaamaa G, Kaiser M, Hills E, Soim A, Zhu M, et al. Racial disparity in hypertensive disorders of pregnancy in New York state: a 10-year longitudinal population-based study. Am J Public Health. 2007;97(1):163-70 Available from: http://www.ncbi.nlm.nih.gov/pubmed/17138931. [cited 2018 Jan 31].

19. Bogaerts A, Witters I, Van den Bergh BRH, Jans G, Devlieger R. Obesity in pregnancy: altered onset and progression of labour. Midwifery. 2013:29(12): 1303-13 Available from: http://www.ncbi.nlm.nih.gov/pubmed/23427851. [cited 2018 Jan 28].

20. Hilliard A, Chauhan S, Zhao Y, Rankins N. Effect of obesity on length of labor in nulliparous women. Am J Perinatol. 2012;29(02):127-32 Available from: http://www.ncbi.nlm.nih.gov/pubmed/22105434. [cited 2018 Jan 31].

21. Carlhäll S, Källén K, Blomberg M. Maternal body mass index and duration of labor. Eur J Obstet Gynecol Reprod Biol. 2013;171(1):49-53 Available from: https://www.sciencedirect.com/science/article/pii/S030121151300412 0?via\%3Dihub. [cited 2018 Jan 31].

22. Vahratian A, Zhang J, Troendle JF, Savitz DA, Siega-Riz AM. Maternal Prepregnancy overweight and obesity and the pattern of labor progression in term nulliparous women. Obstet Gynecol. 2004;104(5, Part 1):943-51 Available from: http://www.ncbi.nlm.nih.gov/pubmed/15516383. [cited 2018 Jan 31]

23. Norman SM, Tuuli MG, Odibo AO, Caughey AB, Roehl KA, Cahill AG. The effects of obesity on the first stage of labor. Obstet Gynecol. 2012;120(1): 130-5 Available from: http://www.ncbi.nlm.nih.gov/pubmed/22914401. [cited 2018 Jan 31].

24. Kominiarek MA, Zhang J, VanVeldhuisen P, Troendle J, Beaver J, Hibbard JU. Contemporary labor patterns: the impact of maternal body mass index. Am J Obstet Gynecol. 2011;205(3):244.e1-8 Available from: http://www.ncbi.nlm. nih.gov/pubmed/21798510. [cited 2018 Jan 31].

25. Chereshneva M, Hinkson L, Oteng-Ntim E. The effects of booking body mass index on obstetric and neonatal outcomes in an inner city UK tertiary referral centre. Obstet Med. 2008;1(2):88-91 Available from: http://www.ncbi. nlm.nih.gov/pubmed/27582791. [cited 2018 Jan 31].

26. Aviram A, Hod M, Yogev Y. Maternal obesity: Implications for pregnancy outcome and long-term risks-a link to maternal nutrition. Int J Gynecol Obstet. 2011;115:S6-10 Available from: http://www.ncbi.nlm.nih.gov/ pubmed/22099446. [cited 2018 Jan 31].

27. Begum KS, Sachchithanantham K, De Somsubhra S. Maternal obesity and pregnancy outcome. Clin Exp Obstet Gynecol. 2011;38(1):14-20 Available from: http://www.ncbi.nlm.nih.gov/pubmed/21485717. [cited 2018 Jan 31].

28. Leticia S-L, Lourdes C, De la V-SE, Leonor R-R, Hernández-Serrato María Isidra WD, et al. Características sociodemográficas y reproductivas asociadas con el aumento de cesáreas en México. Salud Publica Mex. 2013;55:S225-34 Available from: http://www.scielo.org.mx/scielo.php?script=sci_arttext\&pid= S0036-36342013000800020. [cited 2018 Jan 31].

29. World Health Organization (WHO). WHO statement on caesarean section rates [internet]. World Health Organization. World Health Organization; 2015. Available from: http://www.who.int/reproductivehealth/publications/ maternal_perinatal_health/cs-statement/en/. [cited 2018 Jan 31]

30. Chu SY, Kim SY, Schmid CH, Dietz PM, Callaghan WM, Lau J, et al. Maternal obesity and risk of cesarean delivery: a meta-analysis. Obes Rev. 2007;8(5): 385-94 Available from: http://www.ncbi.nlm.nih.gov/pubmed/17716296. [cited 2018 Nov 19].

31. Heredia-Pi I, Serván-Mori E, Reyes-Morales H, Lozano R. Brechas en la cobertura de atención continua del embarazo y el parto en México. Salud Publica Mex. 2013;55(2):249-58.

32. WHO. Mean Body Mass Index (BMI): WHO; 2017. Available from: http://www. who.int/gho/ncd/risk_factors/bmi_text/en/. [cited 2018 Dec 2]

33. CDC. Body mass index: considerations for practitioners. Available from: https:// www.cdc.gov/obesity/downloads/bmiforpactitioners.pdf. [cited 2018 Dec 2]
34. Gibbons L, Belizán JM, Lauer JA, Betrán AP, Merialdi M, Althabe F. The global numbers and costs of additionally needed and unnecessary caesarean sections performed per year: overuse as a barrier to universal coverage world health report (2010) Background paper, 30 HEALTH SYSTEMS FINANCING; Available from: https://www.who.int/healthsystems/ topics/financing/healthreport/30C-sectioncosts.pdf. [cited 2018 Jan 31]

35. Betrán AP, Ye J, Moller A-B, Zhang J, Gülmezoglu AM, Torloni MR. The Increasing Trend in Caesarean Section Rates: Global, Regional and National Estimates: 1990-2014. Zeeb H, editor. PLoS One. 2016;11(2): e0148343 Available from: http://www.ncbi.n/m.nih.gov/pubmed/2684 9801. [cited 2018 Jan 31].

36. Betrán AP, Merialdi M, Lauer JA, Bing-Shun W, Thomas J, Van Look $P$, et al. Rates of caesarean section: analysis of global, regional and national estimates. Paediatr Perinat Epidemiol. 2007;21(2):98-113 Available from: http://www.ncbi.n/m.nih.gov/pubmed/17302638. [cited 2018 Jan 31].

37. Molina G, Weiser TG, Lipsitz SR, Esquivel MM, Uribe-Leitz T, Azad T, et al. Relationship between cesarean delivery rate and maternal and neonatal mortality. JAMA. 2015;314(21):2263 Available from: http://www.ncbi.nlm.nih. gov/pubmed/26624825. [cited 2018 Jan 31].

38. Villar J, Valladares E, Wojdyla D, Zavaleta N, Carroli G, Velazco A, et al. Caesarean delivery rates and pregnancy outcomes: the 2005 WHO global survey on maternal and perinatal health in Latin America. Lancet. 2006; 367(9525):1819-29 Available from: http://www.ncbi.nlm.nih.gov/pubmed/16 753484. [cited 2018 Feb 4].

39. Zhao Y, Zhang J, Zamora J, Vogel JP, Souza JP, Jayaratne K, et al. Increases in Caesarean Delivery Rates and Change of Perinatal Outcomes in Low- and Middle-Income Countries: A Hospital-Level Analysis of Two WHO Surveys. Paediatr Perinat Epidemiol. 2017;31(4):251-62 Available from: http://www. ncbi.n/m.nih.gov/pubmed/28474743. [cited 2018 Jan 31].

40. Heslehurst N, Simpson H, Ells LJ, Rankin J, Wilkinson J, Lang R, et al. The impact of maternal BMI status on pregnancy outcomes with immediate short-term obstetric resource implications: a meta-analysis. Obes Rev. 2008; 9(6):635-83 Available from: http://www.ncbi.nlm.nih.gov/pubmed/18673307. [cited 2018 Jan 31].

41. Crane JMG, Murphy P, Burrage L, Hutchens D. Maternal and perinatal outcomes of extreme obesity in pregnancy. J Obstet Gynaecol Canada. 2013;35(7):606-11 Available from: http://www.ncbi.n/m.nih.gov/pubmed/23 876637. [cited 2018 Jan 31].

42. DiMarco CS, Ramsey PS, Williams LH, Ramin KD. Body mass index as a risk factor for cesarean delivery in the nulliparous parturient. Obstet Gynecol. 2001;97(4):S71.

43. Barau G, Robillard P-Y, Hulsey T, Dedecker F, Laffite A, Gérardin P, et al. Linear association between maternal pre-pregnancy body mass index and risk of caesarean section in term deliveries. BJOG An Int J Obstet Gynaecol [Internet]. 2006;113(10):1173-7. Sept 13 [cited 2018 Jan 31] Available from: http://doi.wiley.com/10.1111/j.1471-0528.2006.01038.x.

44. Bhattacharya S, Campbell DM, Liston WA, Bhattacharya S. Effect of body mass index on pregnancy outcomes in nulliparous women delivering singleton babies. BMC Public Health. 2007;7:168.

45. O'Dwyer V, Farah N, Fattah C, O'Connor N, Kennelly MM, Turner MJ. The risk of caesarean section in obese women analysed by parity. Eur J Obstet Gynecol Reprod Biol. 2011;158(1):28-32.

46. World Health Organization. Robson classification. Implementation manual. Geneva; 2017. p. 51. Available from: http://apps.who.int/iris/bitstream/ handle/10665/259512/9789241513197-eng.pdf;jsessionid=69E453099BF4 OF004B3C2464B73E3CF5? sequence=1. [cited 2018 Oct 4]

47. Stewart FM, Ramsay JE, Greer IA. Obesity: impact on obstetric practice and outcome. Obstet Gynaecol. 2009;11(1):25-31 Available from: http://doi.wiley. com/10.1576/toag.11.1.25.27465. [cited 2018 Jan 31].

48. Sámano R, Chico-Barba G, Martínez-Rojano H, Godínez E, Rodríguez-Ventura AL, Ávila-Koury G, et al. Pre-pregnancy body mass index classification and gestational weight gain on neonatal outcomes in adolescent mothers: a follow-up study. PLoS One. 2018;13(7):e0200361 Available from: http://www. ncbi.nlm.nih.gov/pubmed/30001386. [cited 2018 Nov 26].

49. Esther C, Eugenia F-QM, Emilia R-SM, De-Regil Luz María SR. Gestational weigth gain as a predicted by pregestational body mass index and gestational age in Mexican women. Food Nutr Bull. 2008;29(4):334-9 Available from: https://journals.sagepub.com/doi/pdf/10.1177/156482650802 900410. [cited 2018 Nov 26].

50. Hernández-Higareda S, Pérez-Pérez O-A, Balderas-Peña L-M-A, MartínezHerrera B-E, Salcedo-Rocha A-L, Ramírez-Conchas R-E. Maternal metabolic 
diseases related to pre-pregnancy overweight and obesity in Mexican women with high risk pregnancy. Cirugía y Cir (English Ed). 2017;85(4):2928 Available from: https://www.sciencedirect.com/science/article/pii/S244405 0717300542.. [cited 2018 Nov 26].

51. Instituto Mexicano de Seguridad Social. Reducción de la Frecuencia de Operación de Cesárea. Guía de Práctica Clínica. 2014; Available from: http:// www.cenetec-difusion.com/CMGPC/IMSS-048-08/ER.pdf. [cited 2018 Jan 31].

52. Althabe F, Belizán JM. Rising trend in non-indicated caesarean deliveries: can the trend be reversed? Paediatr Perinat Epidemiol. 2017;31(4):263-6 Available from: http://doi.wiley.com/10.1111/ppe.12369. [cited 2018 Jan 28].

53. Heredia-Pi I, Servan-Mori EE, Wirtz VJ, Avila-Burgos L, Lozano R. Obstetric care and method of delivery in Mexico: results from the 2012 National Health and nutrition survey. PLoS One. 2014;9(8):1-9.

54. Campero L, Hernández B, Leyva A, Estrada F, Osborne J, Morales S. Tendencias de cesáreas en relación con factores no clínicos en un centro de educación para el parto en la Ciudad de México. Salud Publica Mex. 2007;49(2):118-25 Available from: http://www.scielosp.org/scielo.php?script= sci_arttext\&pid=S0036-36342007000200007\&lng=es\&nrm=iso\&tlng=es. [cited 2018 Nov 26].

55. Puentes-Rosas E, Gómez-Dantés O, Garrido-Latorre F. Las cesáreas en México: tendencias, niveles y factores asociados. Salud Publica Mex. 2004;46: 1 Available from: http://www.scielosp.org/scielo.php?script=sci_arttext\&pid= s0036-36342004000100003\&lng=es\&nrm=iso\&tlng=es. [cited 2018 Nov 26].

56. Vallejos Parás A, Espino y Sosa S, Jaimes Betancourt L, Zepeda Tena C, Cabrera Gaytán DA, Arriaga Nieto L, et al. Obstetrician's attitudes about delivery through cesarean section: A study in hospitals at Mexico City. Perinatol y Reprod Humana. 2018;32(1):19-26 Available from: https://www.sciencedirect. com/science/article/pii/S0187533718300359. [cited 2018 Nov 20].

57. Victora CG, Barros FC. Beware: unnecessary caesarean sections may be hazardous. Lancet. 2006;367(9525):1796-7 Available from: http://www.ncbi. nlm.nih.gov/pubmed/16753467. [cited 2018 Jan 31].

58. Roberts RJ. Can self-reported data accurately describe the prevalence of overweight? Public Health. 1995;109(4):275-84 Available from: http://www. ncbi.nlm.nih.gov/pubmed/7667492. [cited 2018 Jan 31].

59. Ortiz-Panozo E, Yunes-Diaz E, Lajous M, Romieu I, Monge A, López-Ridaura R. Validity of self-reported anthropometry in adult Mexican women. Salud Publica Mex. 2017;59(3):266 Available from: http://www.saludpublica.mx/ index.php/spm/article/view/7860. [cited 2018 Feb 4].

60. International Journal of Gynecology \& Obstetrics on behalf of International Federation of Gynecology and Obstetrics. Poster Abstracts. In: International Journal of Gynecology \& Obstetrics [Internet]. London: Wiley; 2018. [cited 2019 Jun 26]. p. 543-991. Available from: http://doi.wiley.com/10.1002/ ijgo.12583.

\section{Publisher's Note}

Springer Nature remains neutral with regard to jurisdictional claims in published maps and institutional affiliations.

Ready to submit your research? Choose BMC and benefit from:

- fast, convenient online submission

- thorough peer review by experienced researchers in your field

- rapid publication on acceptance

- support for research data, including large and complex data types

- gold Open Access which fosters wider collaboration and increased citations

- maximum visibility for your research: over $100 \mathrm{M}$ website views per year

At BMC, research is always in progress.

Learn more biomedcentral.com/submissions 